Ici, vous auriez pu lire un article scientifique de haut niveau

Revues en lutte

\title{
OpenEdition
}

Journals

Édition électronique

URL : http://journals.openedition.org/pa/847

DOI : $10.4000 /$ pa. 847

ISSN : 2273-0362

Éditeur

Université Lumière Lyon 2

Référence électronique

Revues en lutte, «Ici, vous auriez pu lire un article scientifique de haut niveau », Parcours

anthropologiques [En ligne], 14 | 2020, mis en ligne le 19 mars 2020, consulté le 04 septembre 2020.

URL : http://journals.openedition.org/pa/847 ; DOI : https://doi.org/10.4000/pa.847

Ce document a été généré automatiquement le 4 septembre 2020

Parcours anthropologiques 


\section{Ici, vous auriez pu lire un article scientifique de haut niveau}

Revues en lutte

\section{Revues en lutte}

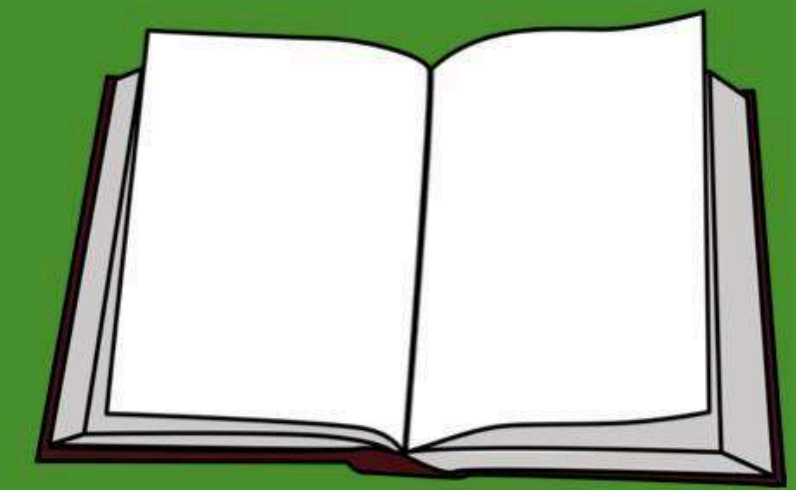

Ici, vous auriez pu lire un article scientifique de haut niveau. Malheureusement, faute de poste, son auteur a dû changer de métier avant de l'avoir écrit... 